\title{
ROMAN JURISTS AND THE CRISIS OF THE THIRD CENTURY A.D. IN THE ROMAN EMPIRE
}

By

\section{LUKAS DE BLOIS}

In this paper I would like to discuss the following questions: did the crisis of the third century A.D. in the Roman Empire finish the strong position of jurists and juridically skilled bureaucrats at the Roman imperial court? Did this crisis usher in the end of their scholarly production?

The period of the Severan dynasty, which preceded the Third Century crisis, has always been regarded as the great age of juridically trained administrators, when Rome's most noted jurists of all time, all of them equites, were appointed to important posts and dominated the imperial council. At least three of them, Papinian, Messius, and Ulpian, became praefecti praetorio $^{1}$. Even though most of the praetorian prefects during the early third century were not lawyers, the influence of jurists was out of all proportion to their numbers and to the length of time during which they were praetorian prefects ${ }^{2}$. After about A.D. 240, however, original scholarly work of learned jurists almost vanished from the earth and military men took the lead in the imperial council and in other key positions. Why did this happen?

Severan emperors regularly appointed two praetorian prefects, a military man next to a jurist or an administrator. This was just a matter of practical expediency, not a fixed system ${ }^{3}$. The jurists among the men they appointed belonged to a kind of learned group, within which the younger ones borrowed ideas from their predecessors and which produced books and treatises that have become classics in Roman law. Most of them did not have any military expertise to speak of. They kept a balance between scholarship, private practice, and public service. Who were they?

A preliminary remark must be made. It is difficult to distinguish juridically skilled administrators or bureaucrats from learned jurists who carried out tasks in the public service. Unlike senators and knights who

\footnotetext{
${ }^{1}$ J. Crook, Consilium principis (New York 1975, 2nd ed.), 79. Messius was probably not Messius Saturninus. Benet Salway has convincingly argued that he was Messius Extricatus, who was a jurist, prefect of the grain supply (210) and a praetorian prefect (c. 212-215) in the Severan period. See B.P.M. Salway, 'A Fragment of Severan History: The Unusual Career of ... atus, Praetorian Prefect of Elagabalus', Chiron 27 (1997), 127-153.

${ }^{2}$ L.L. Howe, The Pretorian Prefect from Commodus to Diocletian (Chicago 1942), $46 \mathrm{f}$.

${ }^{3}$ See Howe 1942, op.cit. (n.2), 47 f.; A.R. Birley, The African Emperor. Septimius Severus (London 1988, 2nd ed.), 164; Salway 1997, op.cit. (n.1), 152.
} 
fulfilled all kinds of posts in the administration of the empire, learned jurists were periti, not generalists. In day-to-day practice, however, quite a few juridically skilled people developed into all-round administrators, except for the military aspects of the Roman imperial administration. Benet Salway likes to call them bureaucrats, not jurists ${ }^{4}$. Their knowledge of Roman law exceeded the common expertise in Roman law and legal procedures, that every experienced Roman governor or administrator obtained during his career. Some of those "bureaucrats" had published treatises on aspects of Roman jurisprudence before they entered a public career, or published scholarly works and served the emperor simultaneously. In this paper I'll call them "juridically skilled administrators or bureaucrats". By "jurists" or "learned jurists" I understand people who dedicated themselves not only to public careers, but equally or even more so to scholarly work. They had a private practice, acted as legal advisers, gave responsa, and wrote books and treatises. The learned jurists from Severan times, whom we know best, are Papinian, Paul, Ulpian, and Modestinus.

Another preliminary remark. Juridically skilled senators and knights had always been members of the imperial council, but - as far as we know now - until the last decades of the second century A.D. they had not mentioned this activity in their career inscriptions. This was still the case in the early Antonine period. Ronald Syme knows of five counsellors of Antoninus Pius, who may be counted as iuris periti. He quotes SHA, Antoninus Pius 12.1: "Multa de iure sanxit ususque est iuris peritis Vindio Vero, Salvio Valente, Volusio Maeciano, Ulpio Marcello et Diaboleno". Three of them were equites, two senators. The name of P. Salvius Iulianus, consul in A.D. 148, should be added ${ }^{5}$. The consilium of Antoninus' successor Marcus Aurelius consisted of twelve splendidi viri, Syme tells us, two of whom were jurists: Q. Cervidius Scaevola and T. Tarrutienus Paternus ${ }^{6}$. According to Syme, many juridically skilled senators and equites, who had been counsellors of Antoninus Pius and Marcus Aurelius, fulfilled successful

\footnotetext{
${ }^{4}$ See Salway 1997, op.cit. (n.1), 152 f.

${ }^{5}$ See W. Kunkel, Herkunft und soziale Stellung der römischen Juristen (Cologne/Vienna 1952, 2nd ed. 1967), 157-214 passim; R. Syme, 'The Jurists approved by Antoninus Pius', in K. Rosen, ed., Antiquitas. Reihe 4. Beiträge zur Historia-Augusta-Forschung (Bonn 1991), 201-213 (quotation from SHA, Antoninus Pius on p. 201).

${ }^{6}$ See Kunkel 1967, op.cit. (n.5), 216-222; Syme, 'Jurists' 1991, op.cit. (n.5), 213-216. According to Zwalve Cervidius Scaevola may have been the last of the great Roman lawyers who were acting as independent legal counsellors and teachers. See his article in this volume. After Scaevola the greatest jurists were imperial procurators and prefects. On Scaevola see also Kunkel 1967, op.cit. (n.5), $217 \mathrm{ff}$. (nr. 53).
} 
careers in the imperial administration. They became juridically skilled administrators. During the latter part of the second century A.D. the prestige of a post within the imperial council may have risen. People who had been members of the consilium principis began to mention this activity in career inscriptions. Marcus Aurelius Papirius Dionysius seems to have been the first to mention a position as consiliarius in his career? ${ }^{7}$. His name betrays a Greek intellectual background. Other early consiliarii were Ti. Claudius Zeno Ulpianus, Q. Valerius Postimius Romulus, and possibly Arrius Menander. Apparently they were trusted, juridically skilled, followers of Septimius Severus and Caracalla. In CIL XI 6337 (= ILS 1422) Zeno is called ex sacra iussione adhibitus in consilium praefecti praetorio item urbi, maybe a deputy to both prefects in times of war, during the first turbulent period of Severus' reign. He had been a procurator ad bona damnatorum before. Q. Valerius Postimius Romulus was a consiliarius Augustorum after having been procurator ad bona damnatorum and procurator ad alimenta ${ }^{8}$. These men were all juridically skilled bureaucrats or administrators. In his contribution in this volume W.J. Zwalve observes that in this way expert legal advice became available within the imperial bureaucracy. Emperors no longer needed legal experts from without. The greatest learned jurists of those days were imperial procurators and prefects. Who were they?

In the Severan age and a few years after the most important learned jurists were Papinian, Paul, Messius, Claudius Tryphoninus, Ulpian, and Modestinus. Opellius Macrinus and Valerius Patruinus were comparable

\footnotetext{
${ }^{7}$ See H.-G. Pflaum, Les carrières procuratoriennes équestres sous le Haut-Empire romain, I-III (Paris 1960-1961, Supplement 1982), I, 472 ff., nr. 181, cf II, 623; see also Kunkel 1967, op.cit. (n.5), 222 ff. (nr. 55). Dionysius was an a libellis et a cognitionibus of Commodus, after having been ducenarius praefectus vehiculorum a copis Augusti per Flaminiam and consiliarius Augusti, probably during the reign of Marcus Aurelius. See also H.-G. Pflaum, Abrégé des procurateurs équestres (Paris 1974), 28. ${ }^{8}$ On Zeno and Romulus see Pflaum, Carr. 1960/1, op.cit. (n.7), II, 604 f., nr. 228, and 644 f., nr. 239. On Zeno see also M. Peachin, Iudex vice Caesaris. Deputy Emperors and the Administration of Justice during the Principate (Stuttgart 1996), 45 f. On Arrius Menander see Kunkel 1967, op.cit. (n.5), 233 f. (nr. 59). Not much is known about him.

${ }^{9}$ See Pflaum, Carr. 1960/1, op.cit. (n. 7), nrs. 220, 228, 231, 248, 294, 314. On the great jurists and juridically skilled bureaucrats of Severan times, esp. on Papinian, Paul, and Ulpian see Kunkel 1967, op.cit. (n.5), 224-261, nrs. 56, 57, 58, 67, 68, and 72; R. Syme, 'Three Jurists', in: Roman Papers II (Oxford 1979), 790-804; Idem, 'Fiction about Roman Jurists', Zeitschrift der Savigny-Stiftung für Rechtsgeschichte 97, Romanistische Abteilung 78 (1980) and Idem 'Jurists' 1991, op.cit. (n.5), 216 f. See also A.M. Honoré, Emperors and Lawyers (London 1981), 15; Idem, Ulpian (Oxford 1982), 3 and B.W. Frier, 'Law on the Installment Plan' (review of A.M. Honoré, Ulpian, Oxford 1982), Michigan Law Review 82, 4 (1984), 857-864; Salway 1997, op.cit. (n.1), 152 f.
} 
juridically skilled bureaucrats ${ }^{10}$. They all reached very important equestrian posts. Papinian, Patruinus, Macrinus, Messius, and Ulpian even became praetorian prefects.

After having been advocatus fisci and a libellis Papinian became praetorian prefect, from 205 to 211. Caracalla dismissed him some time before the murder of Geta. He may have been on the consilium of a previous praetorian prefect ${ }^{11}$. His colleague was a military man, Q. Maecius Laetus ${ }^{12}$. A juridically skilled bureaucrat, who may have been praetorian prefect, in 211-212, was Valerius Patruinus ${ }^{13}$. Opellius Macrinus, who in A.D. 217 became the first equestrian emperor, seems to have been a lawyer from Northern Africa, a follower of Septimius Severus and Plautianus. He may have been advocatus fisci under Severus, a manager of Plautianus' private domains, praefectus vehiculorum, a functionary in the management of the emperor's private fortune, to become praefectus praetorio under Caracalla, with whom he came into close contact during his prolonged stay in the capital. Pflaum remarks: "Notons en tout cas qu'il est toujours employé dans la capitale, ce qui lui permet de faire connaissance de Caracalla, avec l' avènement duquel débute sa véritable ascension". There is no reason to assume that he ever was sole praetorian prefect. In 217-218 Macrinus was the first equestrian emperor ${ }^{14}$.

Ulpian was praefectus annonae in Rome, under Elagabalus, before being praetorian prefect in 222 to 223 or 224 . In his last year he came into conflict with the military in Rome and was murdered ${ }^{15}$. Not much is known

\footnotetext{
${ }^{10}$ Howe 1942, op.cit. (n. 2), 72, nr. 23 (Valerius Patruinus); 72, nr. 25 (Opellius Macrinus); Salway 1997, op.cit. (n.1), 152 n. 128.

${ }^{11}$ Advocatus fisci: see W.J. Zwalve, Keizers, soldaten en juristen. Vijf Romeinse juridische biografieën (Deventer 1998), 22. A libellis: see Dig. 20.5.12 praef. On Papinian see Prosopographia Imperii Romani (from now on PIR), 2nd ed., A 388; Howe 1942, op.cit. (n. 2), 71, nr. 22; Pflaum, Carr. 1960/1., op.cit. (n. 7), II, 583 ff., nr. 220; Kunkel 1967, op.cit. (n.5), 224-229, nr. 56; Syme, 'Three Jurists' 1979, op.cit. (n.9), 790 ff.; Idem, 'Jurists' 1991, op.cit. (n.5), 216 f.; Zwalve, op.cit., 19-53.

${ }^{12}$ Howe 1942, op.cit. (n.2), 71, nr. 21; Salway 1997, op.cit. (n.1), 152 n. 128.

${ }^{13}$ Howe 1942, op.cit. (n.2), 72, nr. 23, says: "The Patruinus murdered with Papinian in 212 at the request of the pretorians (Cassius Dio 77.4.1A; SHA, Vita Caracallae 4.1 f.) was probably praetorian prefect and very likely identical with the Valerius Patruinus, procurator and contemporary of Papinian, quoted as a jurist in Dig. 49.14.50".

${ }^{14}$ See Howe 1942, op.cit. (n.2), 72, nr. 25; Pflaum, Carr. 1960/1, op.cit. (n.7), II, 667-672, nr. 248, esp. 670; Zwalve 1998, op.cit. (n.11), 55-82.

${ }^{15}$ See Howe 1942, op.cit. (n.2), 75, nr. 36; Pflaum, Carr. 1960/1, op.cit. (n.7), II, 762 ff., nr. 294; Kunkel 1967, op.cit. (n.5), 245-254, nr. 68; Syme, 'Three Jurists' 1979, op.cit. (n. 9), 800 f.; Idem, 'Jurists' 1991, op.cit. (n. 5), 216 f. On Ulpian and his work see also Zwalve 1998, op.cit. (n.11), 83114.
} 
about his earlier years. According to Honore he may have served on the court of a praetor and he is said to have been a member of the court of Papinian as praetorian prefect, to have been an a libellis from A.D. 202 to 209 , and to have written most of his many scholarly works in only five years, under Caracalla, but all this is very hypothetical ${ }^{16}$.

Not much is known about the careers of Paul and Modestinus. Paul may have worked for a praetor fideicommissarius and he certainly was a member of Papinian's council (see Dig. 12.1.40). He may have been an $a$ cognitionibus. Syme has convincingly argued that he never was an $a$ memoria. The post was still confined to imperial freedmen, at least under Septimius Severus and Caracalla ${ }^{17}$. Syme also argues, that Paul probably never was a praetorian prefect. He says: "Not without fostering credulity and misconceptions, Papinian and Ulpian both rose to the command of the Guard. The same is alleged for Paulus, but only in the Historia Augusta, in parallel and fraudulent passages (Pescennius Niger 7.4 and Alexander Severus 26.5)"18. On the basis of stylistic arguments Honoré suggests that Modestinus, whom he considers a pupil of Ulpian, became a libellis in 223. We should be careful, though, and not take this for granted. In a review in the Michigan Law Review Bruce Frier has convincingly criticised Honoré's stylometrics. Modestinus may have ultimately reached the position of a praefectus vigilum and disappeared about $241^{19}$. He was the last of the great learned jurists.

Howe, followed by Prickartz, would like to add the future emperor Philippus Arabs. The only evidence they offer are a few rather commonplace passages in Ps. Aelius Aristides' Eis basilea, though, which have nothing to say about Philippus' personal qualities as a jurist ${ }^{20}$. Philippus may have been a specialist in military logistics. In 242 , during Gordian's campaign in

\footnotetext{
${ }^{16}$ See Honoré, Ulpian 1982, op.cit. (n.9), 2 f.; 6-46 and Frier 1984, op.cit. (n.9), 864 (against Honoré's hypotheses).

${ }^{17}$ Syme, 'Three Jurists' 1979, op.cit. (n.9), 794 f.;

${ }^{18}$ Syme, 'Jurists' 1991, op.cit. (n.5), 216. On Paul's career see also Kunkel 1967, op.cit. (n.5), 244, nr. 67; Pflaum, Carr. 1960-1 , op.cit. (n.7), II, 804 ff., nr. 314. On his life and work see also Zwalve 1998, op.cit. (n.11), 115-137. Paul was a pupil of Cervidius Scaevola (Zwalve 1998, op.cit. [n.11], 116 f.). Honoré, Emp.1981, op.cit. (n.9), 15 f., suspects that Paul held the office of an a cognitionibus, but never became praetorian prefect.

${ }^{19}$ See Honoré, Emp.1981, op.cit. (n.9), 76-81; Idem, Ulpian 1982, op.cit. (n. 9), 41. See Frier 1984, op.cit. (n.9), 858 ff. On Modestinus see also Kunkel 1967, op.cit. (n.5), 259 ff., nr 72.

${ }^{20}$ Howe 1942, op.cit. (n.2), 78 f., nr 47; Ch. Prickartz, 'Philippe l' Arabe (244-249), civilis princeps', Antiquité Classique 44 (1995), 136 f. See Ps.-Aelius Aristides, Eis Basilea 5, 11-13, 17-19. See L.de Blois, 'The Eis Basilea of Ps.-Aelius Aristides', Greek, Roman and Byzantine Studies 27 (1986), 279288.
} 
Mesopotamia, he commanded the ships that had to bring supplies to the emperor's army, over the Euphrates ${ }^{21}$.

According to Tony Honoré men like Papinian, Paul, and Modestinus dedicated themselves not predominantly to their public careers. They all had a large private practice and they wrote learned treatises. They acted as legal advisers and gave responsa to parties who started litigation and to other interested people. Many of those responsa were published in series of volumes. Ulpian, on the other hand, published less responsa, but more scholarly works ${ }^{22}$. The public careers of learned jurists took on a predominantly urban character, they did not spend many years in provinces. They obtained functions like consiliarius, a libellis, and a cognitionibus. From the second century it was possible to have an equestrian career in Rome, practically without leaving the city ${ }^{23}$. This gave this group of learned jurists the opportunity to combine public careers with continuous scholarly work and a private practise in the capital.

The age of the great jurists - prefects and of dominant influence of jurists in the imperial council did not last long. Papinian was, from 205 to 211 , the first learned jurist who became praetorian prefect. Three juridically skilled bureaucrats, Valerius Patruinus, Opellius Macrinus, and Messius Extricatus, and the most learned of the Severan jurists, Domitius Ulpianus (Ulpian), followed suit. After about A.D. 241, however, other people became dominant at court. They were specialists in administration, taxation in money or in kind, and military tactics and logistics, men like Timesitheus, Iulius Priscus and the future emperor Philippus Arabs ${ }^{24}$. Modestinus may have been the last great learned jurist who had a more than average influence in the entourage of the emperor. Tony Honoré has demonstrated that from 241 the style of rescripts changed ${ }^{25}$. Learned jurists disappeared again from the centre of power after about A.D. 241, but kept reaching functions like $a$

\footnotetext{
${ }^{21}$ See Zosimus 1.18.3.

${ }^{22}$ Honoré, Ulpian 1982,op.cit. (n.9), 21 f., concludes that the responsa of Papinian and Modestinus both run to 19 books, Paul's to 23, Ulpian's to only 2 . Ulpian wrote more books, though. He published commentaries on the edictum praetoris urbani, on the ius civile, on the tasks of a proconsul, and on disputationes. He also wrote works like De omnibus tribunalibus, Ad legem Iuliam et Papiam, De fideicommissis, De appellationibus, Ad legem Iuliam de adulteriis, and books on the tasks of various magistrates and administrators. See Honoré, Ulpian 1982, op.cit. (n.9), 88-105.

${ }^{23}$ Pflaum 1974, op.cit. (n.7), 32, remarks: "Depuis Trajan, un quart de l' effectif est à Rome, et pour les postes importants la proportion est plus considérable encore (presque un tiers). Un fonctionnaire équestre peut donc désormais, théoriquement, parcourir toute sa carrière sans quitter Rome".

${ }^{24}$ Howe 1942, op.cit. (n.2), 78 f., nos. 45, 46, and 47.

${ }^{25}$ Honoré, Emp. 1981, op.cit. (n.9), 89. In my view, Frier's criticisms do not take this away. See above, nn. 9 and 16.
} 
libellis. Besides, scholarly works like those of Ulpian were no longer written from about A.D. 240. Why did this happen, and why were learned jurists less successful in reaching the highest posts, like the praetorian prefecture?

The traditional view is that the emperors after A.D. 230 were more in need of experienced generals than of jurists, who wrote books, and started to appoint military men to important functions like the praetorian prefecture. True as it is, this answer may be too simple. Moreover, it leaves aside the disappearance of learned juridical publishing.

Indeed, learned jurists were no specialists in military logistics and tactics or in border warfare. Ulpian, but also the other great jurists of those times, were intellectuals like sophists, doctors, philosophers, and scientists. They had more in common with Greek sophists and Latin orators than with most officers. In his The Emperor and the Roman World Fergus Millar makes no difference between sophists, rhetors, and jurists. He rightly treats them as one group ${ }^{26}$. Like those learned jurists Second Sophistic Greek intellectuals displayed their abilities in public, published treatises, carried on a private practise (in rhetorics), acted as patrons and benefactors, and served their communities or the emperor, entering his administrative apparatus as $a b$ epistulis graecis or in other comparable functions. Some of those intellectuals only obtained one or two of these functions as a reward, at the end of their life. A few of them reached higher prefectures and governed Egypt, for example ${ }^{27}$.

Both groups, jurists and sophists, may even have been intertwined. Bowersock observes: "There had long been a connection between the legal profession and the sophists, a connection which arose naturally enough from

\footnotetext{
${ }^{26}$ See F. Millar, The Emperor in the Roman World (London 1992, 2nd ed.), 83-101. On the intellectual activities of Papinian, Paul and Ulpian, see V. Giuffrè, C.A. Maschi and G. Crifò in Aufstieg und Niedergang der Römischen Welt (from now on ANRW) II 15 (Berlin / New York 1976), 632 - 666; 667 $-707 ; 708-789$.

${ }^{27}$ See Philostratus, Vitae Sophistarum (from now on VS) 511-628, esp. 520, 521, 524, 571, 590, 607, 628. See G.W. Bowersock, Greek Sophists in the Roman Empire (Oxford 1969), 17-29 ("Cities of the Sophists"), 43-58 ("Sophists and Emperors") and 101-109 ("The Circle of Iulia Domna"). On Second Sophistic Greek intellectuals see also S. Swain, Hellenism and Empire (Oxford 1996), 135-422; Th. Schmitz, Bildung und Macht (Munich 1997), 67-231; Idem, 'Performing History in the Second Sophistic', in M.Zimmermann, ed., Geschichtsschreibung und politischer Wandel im 3. Jh. n. Chr., Historia Einzelschrift 127 (Stuttgart 1999), 71-92. According to Bowersock, op.cit., 50 f., in the 2nd and early 3rd centuries A.D. 12 Greek-speaking litterati became ab epistulis graecis, and a few of them, like Avidius Heliodorus and Valerius Eudaemon, afterwards emerged as prefects of Egypt. See Pflaum, Carr., op.cit.(n.7), I, 264-271, nr 110 (Valerius Eudaemon) and PIR, 2nd ed., A 1405 (Avidius Heliodorus). Bowersock, op.cit., 49, draws a parallel with the Latin orator Fronto, who also combined literary activities with a private practise and public service.
} 
the forensic activity of rhetors. The explicit testimony of Philostratus reveals the legal competence of Nicetes (VS 511; 516) and Scopelianus (VS 519) as well as the legal character of the rhetoric of Antiochus (VS 569) and Damianus (VS 606). An inscription attests the legal skill of Lollianus"28. Some learned jurists had Eastern Greek backgrounds. Ulpian, for example, came from Tyre $^{29}$, like the great sophist Hadrianus, who on his deathbed was appointed to ab epistulis graecis by the emperor Commodus, just for the sake of honour (Philostratus, VS 590).

There are more parallels between the two groups. During the period of the Late Republic and the early Principate close relations between powerful Roman magistrates, emperors, and Greek intellectuals had existed, but those relationships had not regularly and frequently led to formal appointments to functions within the imperial administration. They had illustrated the continuity of diplomatic traditions of personal friendship, advice, and intercession ${ }^{30}$. Likewise, friendly informal relations between emperors and learned jurists who gave responsa and wrote treatises had always existed in Rome. In the second century, and even earlier, such jurists had regularly been invited to the imperial council, as guests who could give expert advice. Only during the reign of Marcus Aurelius this relation between emperor and jurists took on a more formal aspect. Like sophists and orators, learned jurists are not perceived as a separate group in society in our literary sources. In the works of Cassius Dio and Herodian only the emperors, senators, knights, local notables in their cities, the populace of Rome, the military, and even centurions and caesariani are mentioned as constituent elements of the Roman empire and as groups which have to fulfil a function within the Roman body politic, but not intellectuals like jurists, orators and sophists. They are mentioned individually and subsumed under other social categories ${ }^{31}$.

Before we may try to explain the decay of the power of learned jurists in the years from 241, we should analyse the reasons why they rose to the top under the Severan administration. Why did they rise? Firstly because

\footnotetext{
${ }^{28}$ IG II/III, 2nd ed., 4211. Bowersock 1969, op.cit. (n.27), $56 \mathrm{f}$.

${ }^{29}$ See Honoré, Ulpian 1982, op.cit.(n.9), 9.

${ }^{30}$ Bowersock 1969, op.cit. (n. 27), 43-44.

${ }^{31}$ See L. de Blois, 'Emperor and Empire in the Works of Greek-speaking Authors of the Third Century A.D.', in $A N R W$ II 34, 4, (Berlin/New York 1998), 3408 ff. and 3421. In his 80th Epistle Cyprian mentions senators, equites, clerics, caesariani and rich matronae as the leading elements in North-African Christian communities, which already had started to mirror Roman society. In his persecution of the Christians the emperor Valerian concentrated on these groups.
} 
of necessity. Tony Honore observes: "The office of the praetorian prefects had grown by a process of piecemeal delegation into the most important, next to that of the emperor himself. Mainly a military post, its duties spread from the command of the praetorian guard, stationed in Rome, to the superintendance of the armies in the provinces. Its civil business, especially legal appeals, now increased to the point at which one of the two prefects was sometimes a lawyer. It was thus that Papinian, Macrinus, and Ulpian, men of legal rather than military careers, came to hold this, the highest equestrian office" ${ }^{\prime 2}$. According to Honore the permanent criminal commissions, the quaestiones perpetuae, which from the republic had exercised criminal jurisdiction in Rome, ceased their operations under Septimius Severus ${ }^{33}$. If he is right, this may have added to the workload of the two great prefectures in Rome, the offices of the praefectus urbi and the praefectus praetorio.

Secondly, by personal attention and interest of Septimius Severus. His interest in and knowledge of the law may have derived from his early career $^{34}$. Cassius Dio, who stood in personal contact with Severus, was aware of this inclination of the emperor (Cassius Dio 76.17.1). This is important indeed, as parallel phenomena may indicate. In his elaborate dissertation on Dionysius of Halicarnassus Koen Goudriaan has argued that Greek rhetors and philosophers, who may be considered forerunners of the Second Sophistic, had gone on writing and performing from later Hellenistic times, without becoming important people in the Mediterranean world of their times $^{35}$. He thinks that theatrical epideictic meletai already existed in the days of Dionysius of Halicarnassus. Earlier, Blass and Norden thought that this oratorical genre took its origin in speeches and treatises of Aeschines and Demetrius of Phaleron, fourth century B.C. Greek orators ${ }^{36}$. Only from the days of the emperor Nero, who had a personal interest in Greek culture and

\footnotetext{
${ }^{32}$ Honoré, Ulpian 1982, op.cit. (n.9), 3.

${ }^{33}$ See Honoré, Ulpian 1982, op.cit.(n.9), 3. He refers to P. Garnsey, 'Adultery Trials and the Survival of the quaestiones in the Severan Age', Journal of Roman Studies 57 (1967).

${ }^{34}$ See Honoré, Emp. 1981, op.cit. (n.9), 15; Zwalve 1998, op.cit. (n.11), 2-5. See also the article he has published in this volume. Cf. T.D. Barnes, 'The Family and Career of Septimius Severus', Historia 16 (1967), $87-107$.

$35 \mathrm{~K}$. Goudriaan, Over classicisme. Dionysius van Halicarnassus en zijn program van welsprekendheid, cultuur en politiek I (Amsterdam 1989), 45 f. Cf. Swain 1996, op.cit. (n. 27), 23 ff.; $27 \mathrm{ff}$.

${ }^{36}$ See F. Blass, Die griechische Beredsamkeit in dem Zeitraum von Alexander bis auf Augustus (Berlin 1865), 57 ff.; E. Norden, Die antike Kunstprosa vom VI. Jahrhundert v. Chr. bis in die Zeit der Renaissance (Leipzig 1898), 127.
} 
visited Greek games ${ }^{37}$, the Flavian emperors, and Trajan, who strengthened the empire's position in the East ${ }^{38}$, their activities became popular among emperors, senators and other members of the imperial aristocracy, and so became a first rate status symbol and a fashionable means of selfidentification among Greek-speaking notables and intellectuals in the Roman empire $^{39}$. The status of Greek rhetors and sophists consequently rose. They came out of the shadows of only regional fame and became celebrities in all provinces in which knowledge of Greek was widespread. Some of them were allowed to enter the imperial administration, as we have seen earlier. Likewise the status of philosophers rose as soon as emperors like Trajan and Hadrian had shown personal interest in their ideas, as Johannes Hahn has shown ${ }^{40}$.

Another parallel phenomenon. One of the scapegoats of Lucian of Samosata, Alexander of Abonuteichos, invented a new god, Glycon, and transformed him into a healing power. He earned some fame and success in his own region, Northwestern Asia Minor and adjacent Thrace, but he only became famous on imperial level after a handful of important senators and perhaps even the emperor, Marcus Aurelius, had shown interest in his new cult. His amulets spread throughout the Near East, as Louis Robert has shown ${ }^{41}$.

A third parallel phenomenon. In his own days Apollonius of Tyana may have been a travelling magician and philosopher of regional significance, but his biographer Philostratus could turn him into a Neopythagorean wise man gifted with a superhuman nature and a hero of Greek paideia, who could speak with princes as if they were his equals, after the Severan court had started to show interest in this miracle worker ${ }^{42}$.

${ }^{37}$ See ILS 8794 (Nero's declaration of the liberty of Greece); Plutarch, Flamininus 12.8; Cassius Dio 63.8-11; 14. See T.E.J. Wiedemann, 'Tiberius to Nero', in Cambridge Ancient History X (Cambridge 1996), 254.

${ }^{38}$ See F. Millar, The Roman Near East, 31 B.C. - A.D. 337 (Cambridge, Mass./London 1993), 80-99.

${ }^{39}$ See Schmitz 1997, op.cit. (n. 27), 175 ff.; 181 ff.; 209 ff.

${ }^{40}$ See J. Hahn, Der Philosoph und die Gesellschaft. Selbstverständnis, öffentliches Auftreten und populare Erwartungen in der Hohen Kaiserzeit (Stuttgart 1989), $182 \mathrm{ff}$.

${ }^{41}$ L. Robert, 'Le serpent Glycon d' Abonuteichos à Athènes et Artémis d' Ephèse à Rome, Opera Minora Selecta V (Amsterdam 1989), 747-769. See Lucian, Alexander 27-37; 49; C.P. Jones, Culture and Society in Lucian (Cambridge Mass., 1986), 133-148, esp. $137 \mathrm{ff}$.

${ }^{42}$ See Philostratus, Vita Apollonii, 5.28; 8.1-6. See Hahn 1989, op.cit.(n. 40), 117 f.; J.J. Flinterman, Power, paideia and Pythagoreanism (Amsterdam 1995), 29-51; 60-66; 88-106; 230; L. de Blois, 'Plutarch's Perception of Plato's Political Activities in Syracuse', in A. Pérez Jiménez, et. al., eds., Plutarco, Platon y Aristoteles. Actas del V Congreso Internacional de la I.P.S., Madrid/Cuenca, 4-7 Mayo de 1999 (Madrid 1999), 304. 
Thirdly, jurists came to the fore by patronage and recommendation. During their predominantly urban careers learned jurists had the possibility to meet emperors, important prefects, and status set senators, patricians for example, and to demonstrate their abilities to them, acting as consiliarii and giving responsa. Personal contacts between emperors and their praetorian and urban prefects, within the consilium principis and elsewhere, were quite common and need no corroboration. So those prefects, who had profited by the expertise of jurists, were in a position to recommend them to the emperor. As long as emperors frequently sojourned in Rome, status set senators were likewise important in patronage and recommendation circuits, because they had an important position in the emperor's urban entourage. Military men were aware of this too. Urban inscriptions show that equestrian middle cadre officers and centurions dedicated honorary monuments to such senators, either in public places or in the premises of the men who were to be honoured or in their own homes, as Silvio Panciera will demonstrate in a forthcoming article ${ }^{43}$. Less elevated senators knew this too. In his article on conventions of patronage in senatorial careers under the Principate Paul Leunissen concludes: "The idea that the exercise of patronage on behalf of other senators was at the very least, concentrated within the group of senior members of the ordo, can hardly be dismissed"44. Patrons had to adapt themselves to the existing pecking order, to personal inclinations, preferences and priorities of governing emperors, and to actual needs of the imperial administration. If they wanted to avoid being rebuffed and losing face and status, they had to weigh those factors as well as the abilities of their candidates in a careful way and they had to see to it that they would not

\footnotetext{
${ }^{43}$ See ILS $1080=$ CIL VI 1517, an honorary inscription of centuriones legionis IV Flaviae to M. Servilius Fabianus Maximus; ILS $1190=$ CIL VI 1531 (cf. CIL VI 31673), an inscription voted to L. Valerius Poplicola Balbinus Maximus, consul ordinarius in 233, by L. Septimius Hermogenes, an equestrian tribune of a cohort who later on became a procurator sexagenarius (Pflaum, Carr., op.cit. [n.3], II, 858 f., nr. 331); CIL VI 1503, a dedication to L. Ragonius Papirius Urinatius Larcius Quintianus; ILS $1077=$ CIL VI 1333 (cf. VI 31633), an honorary inscription to L. Aemilius Karus, dedicated by a middle cadre officer. See S. Panciera, 'Onorare l'amico nella sua casa. Amicitia e topografia a Roma e nel suo suburbo', in: A. Chaniotis/M. Peachin, eds., Festschrift G. Alföldy, forthcoming. A fine example of a military man who had greatly profited by the coming to power of an old friend, the emperor Hadrian, is Marcius Turbo. From 117 his star had risen very quickly indeed. See CIL III 14349; SHA, Vita Hadriani 4.2. Hadrian and Marcius met in 95-96, when Hadrian started his career as a military tribune. K.Hopkins, Death and Renewal (Cambridge 1983), 171 ff., calls those senators the 'grand set'. Many of them were amici Caesaris. See Millar 1992, op.cit. (n.26), $110 \mathrm{ff}$.

${ }^{44}$ P.M.M. Leunissen, 'Conventions of Patronage in Senatorial Careers under the Principate', Chiron 23 (1993), 113.
} 
ask too much ${ }^{45}$. Successful patronage also depended on personal contact. In their letters of recommendation Pliny the Younger and Fronto often suggest that they know their candidates' qualities from personal experience or from first hand eye - witness ${ }^{46}$. Chances of patrons and their protégés must have been influenced by the emperor's whereabouts, which determined who would obtain the possibility to meet the ruler personally. Septimius Severus spent many regnal years in Rome and had a personal interest in jurisdiction. Besides he shifted cases from old traditional courts to the two great prefects, whose offices were involved in systematising Roman law anyway. So learned jurists stood a good chance in processes of patronage, recommendation and selection.

After about 241 or even 230 , those three factors stopped working in favour of learned jurists. Like sophists and comparable intellectuals they disappeared from the centre of power. They kept being appointed to the office of the a libellis, and maintained high rates of quality there, throughout the third century A.D. A decay of professional expertise cannot be the explanation of their relative degradation. Tony Honore observes: "Throughout the third century, in times good and bad, the rescript office, under professional guidance, upheld the integrity of Roman law against Greek and provincial practices. Its output changed little during the period, either in substance or style"47. Learned jurists undoubtedly entered the consilia of the iudices vice sacra, deputies of the emperor, most of whom were, like so many learned jurists, Rome-based. In his book on those deputies Michael Peachin has shown that from the days of Septimius Severus iudices vice sacra took over judicial functions of emperors, who were entangled in border warfare or civil strife. The iudices vice sacra were empowered to hear any and every case, i.e. on the first instance or on appeal, that came to them when they served in the emperor's place. Like emperors they dispensed legal advice as well ${ }^{48}$. Peachin knows of fourteen deputies whose careers can be analysed. The majority served in Rome, a few of them

\footnotetext{
${ }^{45}$ Leunissen 1993, op.cit. (n. 44), 101-120.

${ }^{46}$ See Pliny the Younger, Epistulae 1.14.10; 2.13.1 ff.; 10.4; 10.12;10.26; 10.51; 10.87; 10.94; Fronto, Ad Antoninum Pium 9.1 and 2; Ad Marcum 5.37; Ad amicos 1.1 and 1.5. See R.P. Saller, Personal Patronage under the Early Empire (Cambridge 1982), 75 f.; 131 ff.; Millar 1992, op.cit.(n.26), 275 ff.; Leunissen 1993, op.cit. (n. 44), 114 f. See above, n. 14, about the career of Opellius Macrinus. He stood in personal contact with the emperor Caracalla for a long time.

${ }^{47}$ A.M. Honoré, 'Imperial Rescripts A.D. 193-305: Authorship and Authenticity', Journal of Roman Studies 69 (1979), 62.

${ }^{48}$ See Peachin 1996, op.cit.(n.8), 164.
} 
in the East or in the Balkans ${ }^{49}$. Almost all of them were status set senators, who were similar to emperors in lineage, social level, and paideia. They had carried out careers that procured them a broad administrative and financial expertise. They had been iuridici in Italy, legates in civilised inner provinces, curatores of cities, and administrators of road systems, most frequently in Italy. As city-curators they had obtained the opportunity to cement elaborate networks of friendship with local élites, particularly in Italy, but also in the inner provinces, and they had learned to handle intricate financial problems. Like city-curators who served in the provinces the deputies who served outside Italy may have put things in order in war-ridden areas and may have mobilised supplies in the hinterland of important military campaigning ${ }^{50}$. Those deputies could use, of course, expert advice of learned jurists who served in their consilia, but they took over a lot of juridical work and thus made the appointment of learned jurists to high prefectures unnecessary. In this way the rise of those deputies may have contributed to the relative degradation of the learned jurists.

Secondly, patronage and recommendation structures did no longer work in favour of mainly Rome-based learned jurists. From A.D. 230, the emperors needed specialists in military tactics, strategy, and logistics as well as experts in taxation and requisition ${ }^{51}$. So brokers and patrons could less successfully promote unmilitary intellectuals. Besides, from A.D. 230 the emperors were not as often in Rome as before. Military men and

\footnotetext{
${ }^{49}$ Peachin 1996, op.cit. (n.8), 93 ff., nr. 1 (Pollienus Auspex, Rome); 96 ff., nr. 2 (M. Numinius Umbrius Primus Senecio Albinus, Rome, A.D. 208/9); 101 ff., nr. 3 (C. Octavius Appius Suetrius Sabinus, Rome, A.D. 214/5); 106 ff., nr. 4 (Ti. Iulius Pollienus Auspex, Roma, A.D. 218-222); 108 ff., nr. 5 (Anonymus, probably in the East, A.D. 231/3); 112 ff., nr. 6 (L. Caesonius Lucillus Macer Rufinianus, Rome, 242/4); 114 ff., nr. 7 (M. Antonius Memmius Hiero, Asia Minor/Galatia, A.D. 244/5); 119 ff., nr. 8 (Severianus, a relative of Philippus Arabs, Balkans, from A.D. 244); 120 ff., nr. 9 (Anonymous, probably Aspasius Paternus, Syria, A.D. 251/4); 123 ff., nr. 10 (L. Valerius Poplicola Balbinus Maximus, see above n. 43, Rome, A.D. 254-260); 127 ff., nr. 11 (Virius Lupus, Eastern provinces, about A.D. 273; Egypt, A.D. 274); 129 ff., nr. 12 (L. Caesonius Ovinius Manlius Rufinianus Bassus, Rome, A.D. 276/81); 132 ff., nr. 13 (T. Flavius Postumius Titianus, Rome, about A.D. 291/2); 137 ff., nr 14 (L. Aelius Helvius Dionysius, The East, about A.D. 296).

${ }^{50}$ See W. Eck, Die staatliche Organisation Italiens in der Hohen Kaiserzeit (Munich 1979), 190-226; G.P. Burton, 'The curator rei publicae: Towards a Reappraisal', Chiron 9 (1979), 465-487, esp. $482 \mathrm{f}$. A prosopography of curatores rei publicae has been published by F. Jacques, Les curateurs des cités dans l'occident romain (Paris 1983). On the basis of Burton's investigations one may conclude that in Asia Minor regional aristocrats, in local status comparable with status set senators in Italy, were selected to be city curators. Like those senators they had the ascendancy to impress local notables.

${ }^{51}$ Careers of such specialists are to be found in Pflaum, Carr. 1960/1, op.cit. (n.7), II, 625 ff., nr. 234 (Cn. Marcius Rustius Rufinus); 649 ff., nr. 242 (Ti. Claudius Subatianus Proculus); 662 ff., nr 247 (M. Oclatinius Adventus); 752 ff., nr. 290 (P. Valerius Comazon).
} 
administrators, who were active in provincial administration and in the armies, now met the emperors and the leading advisers and functionaries who travelled with them, and were in a position to further careers of people who helped them in their work, i.e. military cadre personnel. Likewise the military man Varius Clemens from Celeia, after he had become ab epistulis under Marcus Aurelius, had been in a position to recommend other military specialists to the emperor, who needed their expertise in those times of heavy warfare in the Danube regions. Among his candidates may have been Pertinax, who was to become emperor in 193, and Maximianus. They were both military upstarts. Varius Clemens may also have furthered the careers of three successful former senatorial legati legionis, Claudius Fronto, Martius Verus, and Avidius Cassius, who were to be promoted to militarily important governorships of consular provinces. So their career between the praetorship and the consulate became very short. Anthony Birley convincingly argues that the appointment of Varius Clemens to ab epistulis, i.e. the most important broker at court, must have been vital to the rise of those five military men under Marcus Aurelius ${ }^{52}$.

Thirdly, the military middle cadres consisting of centurions, primipili, tribuni and praefecti, who were in a good position to influence the soldiers and who were becoming ever more important in the administration of the provinces, obtained a position of great strength within the Roman imperial system and could not be ignored in appointment policies. They stood in close contact with the emperors, who, from A.D. 230, were more often in the provinces than in Rome. According to Brian Dobson, the primipilares in the third century became increasingly involved in administrative duties. They had to collect, among other tasks, a special tax, which became known as the primipilum ${ }^{53}$. Those middle cadres had always been important. In Book 10 of the letters of Pliny the Younger, in Epistle 10.27, military men and caesariani (still largely freedmen in those days)

\footnotetext{
${ }^{52}$ On Varius Clemens see A.R. Birley, Locus virtutibus patefactus? Zum Beförderungssystem in der Hohen Kaiserzeit, Rheinisch - Westfälische Akademie der Wissenschaften, Geisteswissenschaften, Vorträge G-318 (Opladen 1992), 48 nr. 8. On Pertinax, Maximianus, and the three senators see Idem, op.cit., 23 and 27. On Pertinax and Maximianus see also G. Alföldy, 'P.Helvius Pertinax und M.Valerius Maximianus', Situla 14/15 (1974), 199-215 (= Idem, Römische Heeresgeschichte [Stuttgart 1987], $326 \mathrm{ff}$.). The office of the ab epistulis was an important centre of information on possible candidates for all kinds of posts (Birley, op.cit., 18).

${ }^{53}$ See B. Dobson, "The Significance of the Centurion and "Primipilaris" in the Roman Army and Administration', in $A N R W$ II 1 (Berlin/New York 1974), 432; Idem, 'The Primipilares in Army and Society', in G.Alföldy, B.Dobson, W.Eck, eds., Kaiser, Heer und Gesellschaft in der Römischen Kaiserzeit, Gedenkschrift für Eric Birley (Stuttgart 2000), 142; $151 \mathrm{f}$.
} 
were the persons who collected grain in a district of Bithynia-Pontus. In those days, however, not many soldiers and officers had been seconded from the armies on a permanent basis. They still were camping at the borders. Pliny tried to obtain more soldiers, but in vain ${ }^{54}$. In the third century, however, ever more military men stayed in the inner provinces and were permanently involved in administrative tasks, as MacMullen has already shown, as far back as $1963^{55}$. They carried out the requisitions which the government needed to feed the armies and to carry on the wars. Locally and regionally they were rather powerful. Cassius Dio and Herodian considered centurions and caesariani constituent elements of the Roman empire ${ }^{56}$. In the days of Gordian III and Philip the Arabian respectively villagers of Skaptopare in Thrace and Aragoe in Asia Minor sent military men to the emperor, to bring him their petitions ${ }^{57}$. They did not send an orator ar a local celebrity from a nearby town. Military cadre people saw to it, that complaints about the severity of Cassius Dio, as a governor of one of the Pannonias, reached the praetorian guard, which in 229 forced the emperor Severus Alexander to keep Dio out of Rome, although he was a consul ordinarius iterum together with the emperor himself. According to Herodian 7.3.6 hard - pressed provincials complained to military relatives about the greed of the emperor Maximinus Thrax, not to any official authority.

Primipili, centurions, and even lower grades now even had to choose between a tactical military career or an administrative one in the provinces. So much work had to be done that the two could no longer be combined. The military cadre stopped being one social category and was splitting into two different groups ${ }^{58}$. Officers and lower cadre, who opted for administrative work, obtained the expertise and the personal connections with senators, knights, and caesariani, which could procure them good careers.

The military middle cadres were liable to a process of mental and cultural change. In a previous period of warfare the emperor Marcus Aurelius had not hesitated to appoint such career-soldiers, like M. Valerius

\footnotetext{
${ }^{54}$ See Pliny, Epistulae 10.19-22.

${ }^{55}$ See R. MacMullen, Soldier and Civilian in the Later Roman Empire (Cambridge, Mass., 1963).

${ }^{56}$ See De Blois 1998, op.cit. (n.31), 3408 ff.; 3421.

${ }^{57}$ See CIL III Suppl. 12336 = IGR I 674 = Dittenberger, Sylloge (third ed.), 888 (from Skaptopare), line 7.; OGIS 519 = IGR IV 598 (from Aragoe), line 3. Cf. P. Herrmann, Hilferufe aus römischen Provinzen. Ein Aspekt der Krise des römischen Reiches im 3. Jhdt. n.Chr., Joachim Jungius Gesellschaft der Wissenschaften, Hamburg (Göttingen 1990), 19 and 29.

${ }^{58}$ See D.J. Breeze, 'The Career Structure below the Centurionate during the Principate', $A N R W$ II 1 (Berlin/New York 1974), 435-451, esp. 443 ff.; Dobson, 1974 'Significance', op.cit. (n.53), 432; Idem 2000, 'Primipilares', op.cit. (n.53), 139-152.
} 
Maximianus and P. Helvius Pertinax, to important posts ${ }^{59}$. He even appointed a military man, T. Varius Clemens, to the position of an ab epistulis ${ }^{60}$. He carefully saw to it that they were integrated in the existing social and career system. In the third century that may not have been so easy. In a magnificent article in the Gedenkschrift for Eric Birley Geza Alföldy concludes, on p. 53: "Zusammenfassend lässt sich sagen, dass das römische Heer, einst ein Abbild der differenzierten Sozialstruktur des Imperium Romanum, im Laufe der Kaiserzeit innerhalb dieser Struktur allmählich zu einem privilegierten und mächtigen Sonderkörper geworden ist, der in den Militärdistrikten mit der dortigen Bevölkerung eng zusammenwuchs und mit dieser zusammen als 'Militärgesellschaft' eine eigenständige, verhältnismässig homogene soziale Gruppierung hervorbrachte. Die Folgen bestanden darin, dass dieser Apparat, aufgrund seiner Interessen und dank seiner Kraft, mehr und mehr eine politische Eigendynamik entfaltete" ${ }^{\prime \prime}$. The decisive transition to social isolation and 'Eigendynamik' must have come about between 180 and 230 and must have been enhanced by economic problems. In the same Gedenkschrift Michael Speidel has demonstrated that the military stood at the pinnacle of material welfare at the end of the second century and the beginning of the third, but afterwards they may have come under the influence of the continuous debasement of the currency, which undermined the buying power of their pay ${ }^{62}$. By then, the annona militaris, cannot yet have offered them full compensation. During and after this transition-period the military cadres were not always prepared to accept the guidance of unmilitary intellectuals and jurists like Papinian, Macrinus, Ulpian and Cassius Dio. They needed military, logistical and financial specialist who understood their problems and knew how to solve them. Dio had to spend the year of his second consulship outside Rome, because the soldiers of the guard did not accept him. Macrinus could not discipline the soldiers and lost his throne and his life $\mathrm{f}^{63}$. Papinian and Ulpian were murdered by the military

\footnotetext{
${ }^{59}$ See Alföldy 1974, op.cit. (n.52), 199-215; Pflaum, Carr. 1960/1,op.cit. (n.7), I, 438-552 passim.

${ }^{60}$ See Pflaum, Carr. 1960/1, op.cit. (n.7), I, 368 ff., nr. 156; Birley 1992, op. cit. (n.52), $48 \mathrm{nr} 8$.

${ }^{61}$ G. Alföldy, 'Das Heer in der Sozialstruktur des Römischen Reiches', in G.Alföldy, B.Dobson, W.Eck, eds., Kaiser, Heer und Gesellschaft in der Römischen Kaiserzeit, Gedenkschrift für Eric Birley (Stuttgart 2000), 53.

${ }^{62}$ See M. A. Speidel, 'Sold und Wirtschaftslage der römischen Soldaten', in G.Alföldy, B.Dobson, W.Eck, eds., Kaiser, Heer und Gesellschaft in der Römischen Kaiserzeit, Gedenkschrift für Eric Birley (Stuttgart 2000), 92 ff.; R.F. Bland, 'The Development of Gold and Silver Coin Denominations, A.D. 193-253', in C.E. King \& D.G. Wigg, eds., Coin Finds and Coin Use in the Roman World. The Thirteenth Oxford Symposium on Coinage and Monetary History, 25.-27.3.1993 (Berlin 1993), 67-74.

${ }^{63}$ See Cassius Dio 78.34-41 and 80.5; Herodian 5.2.3 ff.; 5.4.1-12.
} 
in Rome $^{64}$. The emperors involved, Caracalla and Severus Alexander respectively, had to condone the deeds.

Growing regional chauvinism may have added to the problems. Under Philippus Arabs the armies in the Balkans hated the officers who had been sent there so much, that the emperor feared that the whole region might be destabilised. These officers were probably easterners who had come with Philippus. His relative Severianus could do nothing against it. He may have been too much of an intellectual, he is one of the iudices vice sacra we know of, and he was undoubtedly an easterner from Philippus' clique ${ }^{65}$.

So the armies, after having become separate blocks in society, now started to exert a decisive influence on appointment policies. Cassius Dio, a contemporary writer, understood very well what was going on. Throughout his 80 books he considers soldiers the main source of power and a destabilising element in society ${ }^{66}$. In the oration which he ascribes to Maecenas, in book 52.26.1, he has Maecenas advise Augustus to oblige senators to train themselves not only in rhetorics, but also in horse-riding and the handling of weapons. He understood that senators, in order to stay at the top, should regain actual contact with the military and earn their respect.

Did the onset of crisis in the third century A.D. bring about the relative degradation of learned jurists within the Roman imperial administration? The answer must be yes. Continuous warfare, civil strife, ensuing epidemics, and the need to feed the armies strengthened the power of the military middle cadre, which, at the head of the soldiers, kept the enemies out, procured supplies, and carried out ever more administrative tasks in the provinces. They must have preferred top level administrators, who had become specialists in military strategy, tactics, and logistics and in the raising of money and supplies in the hinterland of military campaigns, even if local notables were not willing to co-operate. Continuous wartime conditions caused the emperors to stay away from Rome during prolonged periods and so diminished the chances of successful patronage and recommendation of Rome-based people, who fulfilled predominantly urban careers. Besides, in the middle of crisis, they could not have been

\footnotetext{
${ }^{64}$ On the killing of Papinian see Cassius Dio 77.4.1A and Zosimus 1.9.2. On Ulpian's death see Cassius Dio 80.4.2; Zosimus 1.11.3.

${ }^{65}$ See Zosimus 1.21.2: the Balkan troops hated their taxiarchoi and hegemones. On Severianus see Peachin 1996, op. cit (n.8), 119 ff.

${ }^{66}$ See L. de Blois, 'The Perception of Emperor and Empire in Cassius Dio's Roman History', Ancient Society 29 (1998-1999), $275 \mathrm{ff}$.
} 
recommended to really powerful positions anyway. Brokers had to adapt to the circumstances and the ensuing preferences of the emperors.

A consequence of the relative degradation of learned jurists within the imperial administration may have been, that responsa and treatises of the great jurists, who during the first four decades of the third century had obtained a place in the centre of power, now became classic, deriving their status not only from the outstanding qualities of the authors, but also from the high positions which those authors had held. This may have kept their successors from trying to emulate or surpass them, which in its turn may have ended the publication of learned juridical treatises.

Nijmegen, November 2000. 